\title{
The Impact of Corporate Performance on Mental Accounting and Loss Aversion in Financial Decisions
}

\author{
Mona Hassabelrasoul Mohammad ${ }^{1,2}$, Dalal Mohamed Ebrahim Mohamed $^{1}$ \& Elsaid Abd Elazim Tolba Elsharkawi ${ }^{3}$ \\ ${ }^{1}$ Faculty of Commerce, Azhar University, Dakahlia, Egypt. \\ ${ }^{2}$ Collage of Business, Jouf University, Sekkaka, Saudi Arabia. \\ ${ }^{3}$ Faculty of Commerce, Zagazig University, Sharkia, Egypt \\ Correspondence: Mona Hassabelrasoul Mohammad, Collage of Business, Jouf University, Sekkaka, Saudi Arabia.
}

Received: April 20, 2021

doi:10.5430/ijfr.v12n4p259
Accepted: May 18, 2021

Online Published: June 14, 2021

URL: https://doi.org/10.5430/ijfr.v12n4p259

\begin{abstract}
This study investigates the effect of the organization performance on two psychological biases, mental accounting and aversion to loss, on financial decisions to both investors and managers. To achieve this, two experiments are conducted. The first experiment consists of 40 graduate students as investors, while the second one consists of 40 accountants in a real estate company as managers. The results of the study indicate that the performance of companies impacts both mental accounting and aversion to loss of investors, whereas the performance of companies affects the mental accounting of managers in making their financial decisions but does not affect the aversion to loss.
\end{abstract}

Keywords: corporation performance, mental accounting, loss aversion, financial decision, behavioral finance

\section{Introduction}

Traditional financial theories assume that investors behave rationally when making an investment decision. They increase the expected utility function and follow the probabilistic Bayesian rules (Causi, 2017). A rational investor maximizes hisher wealth by distinguishing between potential return and risk in any decision using the available information, such as corporate financial information and performance, risks faced by companies, interest rates and the country's economic conditions. Therefore, policymakers should understand the played role by disclosed financial information in such decisions when evaluating financial reporting practices to meet the needs of investors (Stålnacke, 2019). However, these theories ignore the fact that an investor is a human being who is affected by many biases that are inherent in his/her personality. Bias is a term that is intended to explain behavior, judgment or habits which are affected by various kinds of prejudice or presumption.

The difficulties crossed by the traditional paradigm to explain the investors' behavior have led to the emergence of the behavioral finance, which explores how decisions are made considering irrational biases, which make the decision-making process complex (Sattar et al., 2020). Behavioral finance can be a bridge between theory and practice. It is trying to look deeper on the investor's behavior, understanding why an investor makes some types of investment and why he/she does not make others (Zen, 2017).

Thaler (1980) explains that the aim of behavioral finance is to integrate human behavior with traditional financial theories to create a more comprehensive model of human behavior in the financial decision-making process. This science is concerned with the anomalies that appear in the financial markets, which traditional financial theories fail to explain.

Psychologists note that there are some biases in individuals' beliefs that lead to systematic errors in processing information when making decisions. Therefore, it is important to identify the effects of these behavioral biases, especially if their cognitive errors impact prices and cannot be easily arbitrage away. The researchers find the presence of multiple types of psychological biases in investor behavior, such as mental accounting, over confidence, self-control, and loss aversion (Zia-ur et al., 2017; Chandani \& Ratnalikar, 2020).

Behavioral finance theory attempts to analyze and explain psychological biases and their impact on investor behavior and their implications (Konstantinidis, 2018). Behavioral finance relies on three main pillars: feelings, preferences, and arbitrage (Bondt et al., 2008). 
Behavioral preferences are inconsistent with the principles of expected utility theory regarding attitudes about expected return and risk. Loss aversion, mental accounting, myopic loss aversion, self-control, disposition effect, over confidence, herding, and regret aversion are the most important features of behavioral preferences (Shukla et al., 2020).

The current study focuses on two types of psychological biases; mental accounting and aversion to loss, and whether they are influenced by organization performance in making financial decision form the perspective of managers and investors. This will contribute to a better understanding of these types of biases and how corporate performance affects them.

The study is divided into five sections. The first section presents an overview of the study and behavioral finance. The Second section conveys mental accounting and its definition and components, and how it will be used in accounting research context. The third section covers the aversion to loss concept and its uses in financial research. The fourth section shows the study methodology, the study hypotheses, experimental design, and statistical result. Finally, the fifth section discusses and interprets the findings of the study.

\section{Mental Accounting}

Mental accounting includes individuals' mechanisms to organize their financial activities, evaluate and track them. Mental accounting refers to a series of mental actions undertaken by economic proxies in managing financial activities, evaluating, and maintaining them (Thaler, 1999). Furthermore, Pompian (2006) states that Mental accounting refers to financial decisions coding, classification and evaluation procedures (Atsala, 2016). Mental accounting refers to the division of individuals' monetary assets and their sources into separate mental accounts according to different subjective criteria (Özkan, 2020). In other words, mental accounting describes the decision-maker tendency to isolate certain events in certain mental accounts, so mental accounting is away to subdivide the decision; whatever its nature; to small parts. Therefore, it describes individuals' violation of rationality when making decisions, through the absence of a comprehensive vision of the results.

In consistence with prospect theory, mental accounting provides evidence that decisions made by individuals depend on their previous experiences, which are recorded in their mental structures and rationality (Cruz el al., 2017).

Mental accounting includes three main components as follows (Said et al., 2020):

The first component: coding which refers to how the outcome is perceived and used as a previous experience, in addition to decision-making and subsequent evaluation

The second component: classification which refers to the allocation of activities and funds to specific mental accounts.

The third component of mental accounting focuses on the frequency of evaluating accounts. Accounts may be evaluated weekly, monthly, or yearly. The more frequently an account is evaluated, the more careful the person will be in taking subsequent decisions.

Zhang\& Sussman (2017) explore the role of mental accounting in household spending and investing decisions, indicating that there are some benefits of mental accounting and segregating funds. For example, they can simplify the overwhelming process of financial planning by limiting the complexity of choices that are faced by households and they can help households maintain financial discipline.

Mental accounting is 'used to explain irrational behavior, for example, mental accounting is observed for managers when choosing between merging and disaggregation income statement data. Results show that managers' preferences related to income statement items are consistent with mental accounting (Shanti, 2016).

Bonner, Clor-Proell and Koonce experimental study finds that managers' decisions are consistent with mental accounting expectations. They confirm that managers' presentation preferences reflect mental accounting, which leads to a better evaluation of the company by investors (Bonner et al., 2014).

Road, Barandagh and Hasanzadeh (2013) investigate the relationship between mental accounting and investment decisions in the Tehran Stock Exchange. They find a negative relationship between mental accounting and investors' decisions (Road et al., 2013). Shams, Kordloui\& Dezfuli, examine investors' preference for framing their gains and losses. Results show that investors accumulate losses on the same day and separate profits over different days, which is consistent with the principles of mental accounting, which recommends combining losses and separating profits to obtain a greater benefit (Shams et al., 2012).

To determine the effect of mental accounting on company's performance, Anolam, Okoroafor and Ajaero test the 
components of mental accounting on the profitability of companies. They find a significant relationship between the classification process and the profitability of companies, while there is no significant relationship between the profitability of companies and other components of mental accounting (Anolam, et al., 2015) .

The current study represents an extension of previous work in studying the relationship between mental accounting and firm performance when making a financial decision by investors and managers.

\section{Loss Aversion}

Prospect theory has become the dominant theory to describe choices under risk and uncertainty. Therefore, its explanation of the weight of benefit has become accepted as a psychological mechanism for loss aversion. Prospect theory states that losses are evaluated differently from gains. The theory also suggests that decision-makers give losses higher utility weights than gains, and individuals are averse to risk in the field of gains and take the risk in the field of losses, i.e., aversion to risk turns into the pursuit of risk in the field of gains (Zhao et al., 2020).

Loss aversion is considered behavioral biases, which is one of the important additions to behavioral economics. The expectation theory is the basis for the loss aversion concept. Two psychologists, Daniel Kahneman and Amos Tversky in 1979, are the first to introduce the concept of loss aversion. They conclude that people feel great pain from losing than the happiness from gaining (prospect theory) (Deslatte et al., 2020). Loss aversion is the tendency of investors to avoid loss and being sensitive to it more than for profits. Loss aversion is an important phenomenon in the field of decision making under uncertainty, which refers to the tendency of people to avoid losses than to acquiring gains (Tshuva, 2019). This explains why traders become risk-seekers in losing field and risk-averse in winning ones.

There are two types of myopic loss aversion: an investor who myopic risk aversion will be more willing to accept risk if he evaluates his investment to obtain a high return and the other is an investor who does not accept unknown risks but accepts low returns with known risks, because of either low financial knowledge or a high degree of loss aversion, and therefore financial knowledge reduces loss aversion to some extent (Ullah Khan, 2017).

A negative framing of the problem influences the degree of loss aversion. When the problem is framed negatively, the aversion to loss is more intense. Therefore, the individual makes a different decision when facing a problem with a negative frame (Ameer, 2017).

Loss aversion is a reliable measure of individual differences in risky decision making (Sokol-Hessner\& Rutledge, 2019). Cultural values affect the cognitive biases of investors, e.g., women are more averse to loss than men, unemployed and older individuals are more averse to loss than younger and employed individuals in financial decisions.

Loss aversion with initial wealth as a point of reference provides a better explanation of the observed preferences as any decision is based on a reference point. The degree of aversion to loss depends on previous gains and losses. Alternatively, losses are less painful than usual when they come after previous profits since they are cushioned by those profits. However, losses are more painful than usual for the loss that comes after other losses due to the increased sensitivity of individuals to additional setbacks which means that investors exhibit a behavior to avoid risks significantly when they encounter a profit, and when they face a loss they continue to hold investments in the hope that the price will rise again (Zen, 2017).

To determine the effect of loss aversion on pricing, Easley\& Yang (2015) and Guo\& He (2017) study the relationship between loss-averse and non-loss-averse investors. The main conclusion of the two studies is that the imbalance that result from loss aversion makes loss-averse investors to not hold risky assets, which reduces the impact of loss aversion on pricing. Therefore, when determining the implications of loss aversion, the heterogeneity of the investor base must be taken into account.

To determine the financial implications of loss aversion, four related issues are found: the first is to pinpoint the extent of individuals' participation in mental accounting when evaluating financial investments in several assets. The second issue is related to the reference point. The third issue is concerned to the extent to which investors evaluate their profits or losses repeatedly while the last issue relates to the realization of trading profits to be calculated as profit (Yang, 2019).

Previous literature have studied the effect of behavioral biases of individuals on their investment decisions, as some biases in individuals 'beliefs lead to errors in processing information when making decisions, but previous studies did not reveal the impact of companies' financial performance on the behavioral biases of individuals and their reflection on financial decisions. This study complements previous research on mental accounting, loss aversion, to 
demonstrate how corporate performance affects loss-aversion mental accounting for both investors and managers when making financial decisions.

\section{Study Methodologies}

\subsection{Methods}

The research uses the experiment method. The experiment includes both postgraduate students and accountants Participants. Students play investor role because they have a reasonable level of business knowledge while accountants play manager role. Accountants should have at least three years of work experience. Although the participants are not actual managers, they can serve as appropriate alternatives for making decisions related to investing in the same industry or in another industry (mental accounting), or investing in companies that achieve a higher return with high risks or investing in companies that achieve a reasonable return with less risks (loss aversion). Depending on the companies' performance (profit or loss), the study tool was developed in 4 scenarios.

The study contains two experiments on two groups, the first group represents investors and the second group represents managers. The aim of the two experiments is to explore the behavioral biases (mental accounting and aversion to loss) in financial decisions, and how the company performance affects this. The caused variable (independent) of the study is the corporate performance, which is measured by profit or loss. Result variables (dependent) of the study are mental accounting and aversion to loss. Mental accounting is measured by investing in the same industry or in different industries. Huang (2019) states that according to mental accounting, each industry is viewed as a separate mental account, and then investors rebalance their portfolios within each industry, not at the level of industries, and thus investors' future purchases are affected by their previous returns in the industry. If the investors have previous high returns in an industry, their tendency is to purchase new shares in this industry will increase due to mental accounting. Aversion to loss is measured by investing in companies with high profits under high risk or investing in companies with low profits under low risks. Zhang (2017) states that individuals are willing to take risks after achieving previous gains, and they avoid risks when a previous loss is realized.

\subsection{Study Hypotheses}

H1: There is no significant relationship between the performance of companies and mental accounting in the financial decisions of investors.

$\mathrm{H} 2$ : There is no significant relationship between the performance of companies and aversion to loss in financial decisions of investors.

H3: There is no significant relationship between the performance of companies and mental accounting in the financial decisions of managers.

H4: There is no significant relationship between the performance of companies and aversion to loss in the financial decisions of managers.

\subsection{The First Experiment}

The first experiment objectives are the following:

1- Testing the impact of the performance of companies as Cause variable on the use of mental accounting in financial decisions of investors as a result variable.

2 - Testing the impact of the performance of companies as a Cause variable on the use of aversion to loss in the financial decisions of investors as a result variable.

\subsubsection{Experiment Design and Sampling}

The sample of the participants in the experiment consists of (40) post graduate students as investors. The experiment is conducted based on Shanti (2016)'s study. The experiment is designed using factor design, where the condition (within subject) namely (profit and loss) is crossed with the presentation (between subjects) to invest in the same industry or in different industry and investing in companies that make high profits under high risks and investing in companies that make low profits under low risks.

Four scenarios are presented to the participants:

The first scenario: the case of profits and financial decisions associated with it (investment in the same industry, or in different industry).

The second scenario: the case of losses and financial decisions associated with it (investment in the same industry, or in different industry). 
The third scenario: The case of the profits and associated financial decisions from (investing in companies that make high profits at high risks, or investing in companies that make low profits at low risks).

The fourth scenario: The case of losses and associated financial decisions from (investing in companies that make high profits at high risk or investing in companies that make low profits at low risks).

4.3.2 Results and Findings

Table 1 presents descriptive statistics for the responses of the participants.

Table 1. Statistic descriptive (Means)

\begin{tabular}{|c|c|c|c|c|}
\hline \multirow{2}{*}{$\begin{array}{l}\text { Company } \\
\text { performance }\end{array}$} & \multicolumn{2}{|l|}{ Mental accounting } & \multicolumn{2}{|l|}{ Loss aversion } \\
\hline & The same industry & Different industry & $\begin{array}{l}\text { High Profits } \\
\text { High Risk }\end{array}$ & $\begin{array}{l}\text { withLow Profits with Low } \\
\text { Risk }\end{array}$ \\
\hline Profit & $93 \%$ & $7 \%$ & $71 \%$ & $29 \%$ \\
\hline Loss & $1 \%$ & $99 \%$ & $26 \%$ & $74 \%$ \\
\hline
\end{tabular}

It is clear from the previous table that when the performance of companies is profit, $93 \%$ of investors tend to invest in the same industry, $7 \%$ of investors tend to invest in a different industry. In case of company's performance is loss, $1 \%$ of individuals tend to invest in the same industry and $99 \%$ of individuals tend to invest in a different industry. In addition, when the performance of companies is profit, $71 \%$ of investors want to invest in profitable companies with higher risk and $29 \%$ of investors want to invest in companies with lower profits and less risk, while in the case of loss, $26 \%$ of investors want to invest in high-profit companies and high risk and $74 \%$ of investors invest in companies with low profits and low risk.

To test hypotheses MANOVA Test (Factorial Design) with SPSS 25 is used, Table (2) shows the results of MANOVA test.

Table 2. MANOVA (Factorial Design) tests of between-subjects effects dependent

\begin{tabular}{lrll}
\hline Variable & & F & SIG \\
\hline $\mathrm{CP}$ & $\begin{array}{r}\text { Mental accounting } \\
\text { Loss aversion }\end{array}$ & 56.316 & 0.000 \\
\cline { 3 - 4 } & 19.909 & 0.000 \\
\hline
\end{tabular}

Table 2 shows that the performance of companies (profit or loss) affects the mental accounting of investors in making their financial decisions (Sig. 0,000), which means that the decision to invest in the same industry or in another industry depends on the performance of companies (profit or loss). This means that when companies have profit, investors tend to invest in the same industry as individuals place companies in the same industry in a single mental account, and when companies' performance is a loss, investors tend to invest in a different industry. Therefore, the first hypothesis is rejected, which means that the performance of companies impacts the mental accounting of investors when making financial decisions.

As can be seen in Table 2, the performance of companies affects investors' aversion to loss when making their financial decisions (Sig. 0,000), which means that the decision to invest in high profit and high-risk companies is affected by their performance. When the performance of companies is profit, investors want to invest in profitable companies with higher risk, while if the corporate performance is loss, investors tend to invest in companies with low profit and risk, and therefore the second hypothesis is rejected, which means that the performance of companies impacts the aversion to loss when making financial decisions. This happen because individuals are more sensitive to loss, especially after previous losses, so they avoid the risk.

\subsection{Second Experiment}

The objectives of the second experiment are as follows:

- Testing the impact of the performance of companies as a Cause variable on the use of mental accounting in the 
financial decisions of managers as a result variable.

- Testing the impact of the performance of companies as a Cause variable on the use of aversion to loss in the financial decisions of managers as a result variable.

\subsubsection{Experiment Design and Sampling}

The sample of the participants in the experiment consists of (40) accountants in a real estate company as managers in the experiment. The experiment is designed using factor design, where the condition (within subject) namely (profit and loss) are crossed with presentation (between subject) to invest in the same industry or in a different industry and investing in companies that make high profits under high risks and investing in companies that make low profits under low risks.

Four scenarios are presented to the participants:

The first scenario: the case of profits and financial decisions associated with it (investment in the same industry, or in a different industry).

The second scenario: the case of losses and financial decisions associated with it (investment in the same industry or in a different industry).

The third scenario: The case of the profits and associated financial decisions from (investing in companies that make high profits at high risks, or investing in companies that make low profits at low risks).

The fourth scenario: The case of losses and associated financial decisions from (investing in companies that make high profits at high risk or investing in companies that make low profits at low risks) .

\subsubsection{Results and Findings}

Table 3 depicts descriptive statistics for the responses of the structured participants.

Table 3. Statistic descriptive (Means)

\begin{tabular}{lllll}
\hline & Mental accounting & \multicolumn{2}{l}{ Loss aversion } \\
\hline $\begin{array}{l}\text { Company } \\
\text { performance }\end{array}$ & The same industry & Different industry & $\begin{array}{l}\text { High } \\
\text { High Risk }\end{array}$ & $\begin{array}{c}\text { Profits } \\
\text { Risk }\end{array}$ \\
\hline Profit & $62 \%$ & $38 \%$ & $49 \%$ & $51 \%$ \\
\hline Loss & $0 \%$ & $100 \%$ & $41 \%$ & $59 \%$ \\
\hline
\end{tabular}

It is shown in Table 3 that when companies performance is a profit, $62 \%$ of investors tend to invest in the same industry, $38 \%$ of individuals tend to invest in a different industry. Nevertheless when the performance of companies is a loss, $0 \%$ of individuals tend to invest in the same industry and $100 \%$ of individuals tend to invest in a different industry. In addition, when the performance of the companies is profit, $49 \%$ of investors want to invest in profitable companies with higher risk and $51 \%$ want to invest in companies that make low profits under low risk, but if the company's performance is loss, $41 \%$ of investors tend to invest in companies with high profits and risks and 59\% of investors invest in companies with low profits and low risks.

To test hypotheses MANOVA Test (Factorial Design) with SPSS 25 was used, Table (4) shows the results of MANOVA test.

Table 4. MANOVA (Factorial Design) tests of between-subjects effects dependent

\begin{tabular}{llll}
\hline \multicolumn{2}{l}{ Variable } & F & SIG \\
\hline $\mathrm{CP} \quad$ Mental accounting & 63.960 & 0.000 \\
& Loss aversion & 0.417 & 0.512 \\
\hline
\end{tabular}

As shown in the previous table the performance of companies whether profit or loss affects the mental accounting of managers in making their financial decisions (Sig. 0,000) which means that the decision to invest in the same 
industry or in another industry depends on the performance of companies (profit or loss). This means that when the performance of companies is profit, managers tend to invest in the same industry as individuals place companies in the same industry in a single mental account. When companies' performance is loss, managers tend to invest in a different industry. The third hypothesis is rejected, which means that the performance of companies impacts on the mental accounting of managers when making financial decisions. It is apparent in the previous table that the performance of companies does not affect managers' aversion to loss in making their financial decisions (Sig. 0.521), which means that the decision to invest in companies that make high profits and take high risks is not affected by the performance of companies. Consequently his fourth hypothesis is accepted, which means that the performance of companies does not affect the bias of aversion to loss on managers when making their financial decisions.

\section{Discussion}

Financial decision-makers, like other individuals, subject to some behavioral biases in their decision-making process. Although they analyze all key data such as profits and the market conditions, there are irrational factors affecting their financial decisions. The most important features of behavioral biases are mental accounting, and aversion to loss. Mental accounting denotes to the tendency of an individual to place certain events in different mental accounts. This bias is obvious in the investment in capital markets when investors divide their funds into separate accounts for different reasons, and each part is evaluated differently depending on its source. For example, each industry is viewed as a separate mental account, so investors rebalance portfolios within each industry, and not at the level of all industries which makes future investors' purchases are affected by their previous returns in the industry. If investors have previous high returns in an industry, their tendency to buy new shares in the industry will increase due to mental accounting.

Aversion to loss reflects decision-making under risk. According to this concept, individuals are more sensitive to losses than to profits, and the degree of aversion to loss depends on previous gains and losses. Losses that follow earlier gains are less painful than usual because the loss is mitigated by early profits, and the loss that follows previous losses is more painful than usual because individuals are more sensitive to additional setbacks. Therefore, when individuals achieve previous profits, they will become more risk-tolerant, which makes them invest in companies that make higher profits with higher risks, and in case of losses, investors avoid risks by investing in companies that make low profits in order to take low risks, and this is what has been shown in the behavior of investors.

\section{Conclusion}

This paper examined the impact of companies' performance -expressed in profit or loss- on tow behavioral biases mental accounting and loss aversion - when making financial decisions, whether for investors or managers. The results indicate that:

1- The performance of the company affects the mental accounting and aversion to loss for investors when making their decisions.

2- As for managers, the situation differs, as the results indicate that the company's performance has a noticeable effect on mental accounting, while it does not affect the Aversion to loss. One reason for this could be their experience, so financial knowledge reduces the effect of behavioral biases on the decision-making process.

However, the results of this study should be interpreted with caution since they are subject to several limitations. First: The number of participants in the two trials is small, Second: Two types of behavioral biases have been studied, namely mental accounting, aversion to loss, and the investor's decision may be affected by many other behavioral biases, Third: The first experiment was conducted on graduate students as investors. The results could be different if the study was conducted on actual investors to see the extent of the effect of behavioral biases on their financial decisions, Fourth: The second experiment was conducted on accountants as managers. The results of the study may differ if the study was conducted on actual managers, in addition to the lack of financial awareness among investors in the Egyptian environment,

Therefore, it is suggested that future studies take place in different environments and on actual investors and managers, in addition to studying other types of behavioral biases that may affect investors and managers when they interpret financial information for companies and thus make financial decisions.

\section{References}

Ameer, B. A. (2017). Behavioral factors and their impact on individual investors' decision making and investment performance: empirical investigation from Pakistani stock market. Global Journal of Management and Business 


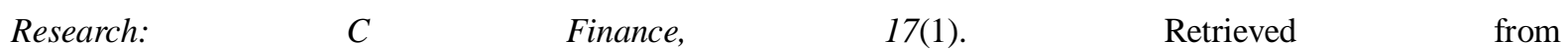
https://journalofbusiness.org/index.php/GJMBR/article/view/2231/2133

Anolam, O. M., Okoroafor, S. N., \& Ajaero, O. O. (2015). Effect of mental accounting on corporate profitability. West African Journal of Industrial \& Academic Research, 14(1), 100-114. Retrieved from https://www.ajol.info/index.php/wajiar/article/view/128084

Atsala, B. (2016). Behavioural finance: the literature review of myopic loss aversion, education in the 21th Century: Responding to Current Issues Conference (pp. 162-168). Retrieved from https://core.ac.uk/download/pdf/267023544.pdf

Bondt, W., Muradoglu, G., Shefrin, H., \& Staikouras, S. K. (2008). Behavioral finance: quo vadis?. Journal of Applied Finance, 1-13. Retrieved from https://ssrn.com/abstract=2698614

Bonner, S., Clor-Proell, S., \& Koonce, L. (2014). Mental accounting and disaggregation based on the sign and relative magnitude of income statement items. The Accounting Review, 89(6), 2087-2114. https://doi.org/10.2308/accr-50838

Causi, G. L. (2017). Theories of investor behavior: from the efficient market hypothesis to behavioral finance. Bachelor's Thesis, Tallinn University of Technology. Retrieved from https://digikogu.taltech.ee/en/Download/2b997790-5dc1-4f6b-8014-e1dcd47ce29f/Investeerimiskitumiseteooria defektiivsestturu.pdf

Chandani, A., \& Ratnalikar, V. A. (2020). Study on human behavioral aspects on individual financial decisions in Indian Context. E-journal-First Pan IIT International Management Conference-2018. https://doi.org/10.2139/ssrn.3753021

Cruz, I., Azevedo, G., \& Silva, A. (2017). Mental accounting: a systematic review. Estudos Do Isca, 5(15), 1-34. Retrieved from https://proa.ua.pt/index.php/estudosdoisca/article/view/1189

Deslatte, A., Swann, W., \& Feiock, R. C. (2020). Performance, satisfaction, or loss aversion? A meso-micro assessment of local commitments to sustainability programs. Journal of Public Administration Research and Theory, 31(1), 201-217. https://doi.org/10.1093/jopart/muaa021

Easley, D., \& Yang, L. (2015). Loss aversion, survival, and asset prices. Journal of Economic Theory, 160, 494-516. https://doi.org/10.2139/ssrn.1784367

Frydman, C., Hartzmark, S. M., \& Solomon, D. H. (2018). Rolling mental accounts. The Review of Financial Studies, 31(1), 362-397. https://doi.org/10.1093/rfs/hhx042

Gal, D., \& Rucker, D. (2018). The loss of loss aversion: will it loom larger than its gain?. Journal of Consumer Psychology, 28(3), 498-546. https://doi.org/10.1002/jcpy.1047

Guo, J., \& He, X. (2017). Equilibrium asset pricing with Epstein-Zin and loss-averse investors. Journal of Economic Dynamics and Control, 76, 86-108. https://doi.org/10.1016/j.jedc.2016.12.008

Huang, X. (2019). Mark twain's cat: Investment experience, categorical thinking, and stock selection. Journal of Financial Economics, 131(2), 404-432. https://doi.org/10.1016/j.jfineco.2018.08.003

Kahneman, D., \& Smith, V. (2002). Foundations of behavioral and experimental economics, advanced information on the prize in economic sciences. Retrieved from http://citeseerx.ist.psu.edu/viewdoc/download?doi=10.1.1.139.386\&rep =rep1\&type=pdf

Kahneman, D., \& Tversky, A. (1979). Prospect theory: an analysis of decision under risk. Econometrica, 47(2), 263-291. https://doi.org/10.2307/1914185

Konstantinidis, A., Spinthiropoulos, K., \& Mallidis, I. (2018). Behavioral Finance and Investment Advisers. Journal of Business and Management, 20(7), 30-33. Retrieved from https://www.academia.edu/download/57145878/E2007083033.pdf

Özkan, M. (2020). Financial evaluation of mental accounting. Journal of Accounting, Finance and Auditing Studies, 6(1), 86-118. https://doi.org/10.32602/jafas.2020.006

Road, E. P., Barandagh, M. I., \& Hasanzadeh, M. (2013). Examining the impact of mental accounting on the investment decision in the Tehran stock exchange. International Journal of Accounting Research, 1(5), 6-10. Retrieved from http://www.arabianjbmr.com/pdfs/AC_VOL_1_5/2.pdf

Said, R., Laba, A., \& Hamid, N. (2020). Determinant of investor behavior of investment decisions in Makassar 
college student investors. American International Journal of Business Management, 3(6), 40-48. Retrieved from https://www.aijbm.com/wp-content/uploads/2020/06/D364048.pdf

Sattar, M. A., Toseef, M., \& Sattar, M. F. (2020). Behavioral finance biases in investment decision making. International Journal of Accounting, 5(2), 69-75. https://doi.org/10.11648/j.ijafrm.20200502.11

Shams., M, F., Kordloui, H., \& Dezfuli, H. K. (2012). The effect of mental accounting on sales decisions of stockholders in Tehran stock exchange. World Applied Sciences Journal, 20(6), 842-847. Retrieved from https://citeseerx.ist.psu.edu/viewdoc/download?doi=10.1.1.388.5004\&rep=rep1\&type=pdf

Shanti. (2016). Mental accounting in managers' preferences related to aggregation versus disaggregation income statement items. Journal of Business and Economics Review, 1(1), 26-33. Retrieved from https://ssrn.com/abstract=3000228

Shukla, A., Rushdi, N. J., \& Katiyar, R. C. (2020). Impact of behavioral biases on investment decisions 'a systematic review'. International Journal of Management, 11(4), 68-76. Retrieved from https://ssrn.com/abstract=3600023

Sokol-Hessner, P., \& Rutledge, R. (2019). The psychological and neural basis of loss aversion. Current Directions in Psychological Science, 28(1), 20-27. https://doi.org/10.1177/0963721418806510

Stålnacke, O. (2019). Individual investors' information use, subjective expectations, and portfolio risk and return. The European Journal of Finance, 25(15), 1351-1376. https://doi.org/10.1080/1351847x.2019.1592769

Thaler, R. (1985). Mental accounting and consumer choice. Marketing Science, 4(3), 199-214. https://doi.org/10.1287/mksc.4.3.199

Thaler, R. H. (1999). Mental accounting matters. Journal of Behavioral Decision Making, 12(3), 183-206. https://doi.org/10.1002/(sici)1099-0771(199909)12:3\%3C183::aid-bdm318\%3E3.0.co;2-f

Tshuva, K. (2019). The Complexity of Choice and Loss Aversion. Ph.D. Thesis, Economics at Barllan University. Retrieved

from

https://econ.biu.ac.il/sites/econ/files/shared/tshuva/the_complexity_of_choice_and_loss_aversion.pdf

Ullah Khan, M. (2017). Impact of availability bias and loss aversion bias on investment decision making, moderating role of risk perception. Journal of Modern Developments in General Management \& Administration, 1(1), 17-28. $\quad$ Retrieved from http://www.impactjournals.us/download/archives/1-82-1502108083-3.man-\%20Impact\%20of\%20Availability\% 20Bias\%20and\%20Loss\%20Aversion\%20Bias\%20on\%20Investment\%20Decision\%20Making.pdf

Yang, L. (2019). Loss aversion in financial markets. Journal of Mechanism and Institution Design, 4(1), 119-137. https://doi.org/10.22574/jmid.2019.11.005

Zen, F. (2017). Behavioural finance and mifid ii. PhD Thesis, University Of Padua. Retrieved from http://tesi.cab.unipd.it/59244/1/Brixhilda_Markvukaj.pdf

Zhang, C. Y., \& Sussman, A. B. (2017). The role of mental accounting in household spending and investing decisions, forthcoming. In C. Chaffin (Ed.), Client Psychology (pp. 7-19). New York: Wiley Chicago Booth Research Paper. https://doi.org/10.1002/9781119440895.ch6

Zhao, W., Walasek, L., \& Bhatia, S. (2020). Psychological mechanisms of loss aversion: A drift-diffusion decomposition. Cognitive Psychology, (123), 1-22. https://doi.org/10.1016/j.cogpsych.2020.101331

Zia-ur, R., Rizwan, M. F., \& Abbas, Z. (2017). Impact of behavioral biases on long term financial decisions and corporate performance: an evidence from non-financial sector of Pakistan. NICE Research Journal, 10(1). Retrieved from https://nicerjss.com/index.php/JFME/article/view/29/26

\section{Copyrights}

Copyright for this article is retained by the author(s), with first publication rights granted to the journal.

This is an open-access article distributed under the terms and conditions of the Creative Commons Attribution license (http://creativecommons.org/licenses/by/4.0/). 